\title{
A Study of Antibioactivity of Nanosilver Colloid and Silver Ion Solution
}

\author{
Kuo-Hsiung Tseng, Heng-Lin Lee, Der-Chi Tien, Ya-Lan Tang, and Yi-Syuan Kao \\ Department of Electrical Engineering, National Taipei University of Technology, Taipei 10608, Taiwan \\ Correspondence should be addressed to Kuo-Hsiung Tseng; khtseng@ee.ntut.edu.tw
}

Received 2 July 2014; Accepted 28 August 2014; Published 14 September 2014

Academic Editor: Protima Rauwel

Copyright (C) 2014 Kuo-Hsiung Tseng et al. This is an open access article distributed under the Creative Commons Attribution License, which permits unrestricted use, distribution, and reproduction in any medium, provided the original work is properly cited.

\begin{abstract}
The colloidal silver solution was successfully prepared in dielectric fluid by using electrical spark discharge (ESD) without any surfactants. It does not require the toxic chemical agents in the process, which may affect the effectiveness of nanosilver colloid as an antibacterial agent. Nanocolloidal silver produced by ESD is characterized as low cost, zero environmental pollution, continuous, and rapid mass production process. In order to test the effect of antibioactivity, nanosilver dough was tested; the silver nanofluid was prepared by ESD machine, made into dough at different concentrations, and fermented for three hours in order to observe changes in the diameter of the dough. The results showed that the effect of effectiveness of nanosilver at the concentration of $100 \mathrm{ppm}$ was weak, whereas the effect of $60 \mathrm{ppm}$ silver ion $\left(100 \mathrm{ppm} \mathrm{AgNO}_{3}\right)$ was significant, as the dissociation rate of silver ion concentration correlates to the antibioactivity.
\end{abstract}

\section{Introduction}

Using ESD to prepare nanoproducts is a feasible method, which can process super hard materials (electrodischarge machining equipment) in the earliest stages. Traditional electric discharge machining (EDM) places the tool electrode and work piece in an insulating working fluid and applies DC voltage to the two poles. In recent years, nanotechnology has developed rapidly, and the research of ESD has focused on the characteristics and applications of nanoparticles or fluid in dielectric fluid [1]. For ESD processing, a set of continuous preparation methods has been developed [2-4], which can effectively be applied to mass production and further developed toward nanotechnology applications. The heat generated by ESD melts the surface of the electrode into metal particles or charged ions and then sputters and dissolves them in the dielectric fluid [5].

As a result of the abuse of antibiotics, bacterial resistance has continued to increase, thereby decreasing the antibiotic potency. Hence, efforts have been made in seeking alternative traditional antibacterial materials. Among the new antibacterial materials, silver nanoparticles and silver ion are the rising stars for resisting bacteria in the postantibiotic era, especially silver ion, which dominates sterilization. Recent studies have found that some metal ions have oxidative antibiosis, and the descending order of oxidizing power is $\mathrm{Ag}>\mathrm{Cu}>\mathrm{Cr}>$ $\mathrm{Ni}>\mathrm{Zn}>\mathrm{Fe}$. As positively charged silver ion has the best reducing force, it is oxidized by oxygen $(\mathrm{O})$ to generate oxyanion free radicals with a bactericidal mechanism. Silver is an efficient antibacterial material that has long been studied $[6-8]$, as it can inhibit fungi, viruses, and bacteria [9-15]. Literature [16] found that $20 \mathrm{ppm}$ silver ion is required to fight Staphylococcus aureus. In biomedical materials, silver nanoparticles can dissociate silver ions [17-21] and enter cell membranes at low concentrations, thus reducing the enzyme activity in bacteria and obstructing biochemical synthesis to result in antibacterial action.

\section{Research Method and Process}

2.1. Preparation of Nanosilver by Electrical Spark. The metal nanoparticles were chemically prepared previously, with an added suspending agent to control nanoparticle size and concentration. This study used ESD to split silver material into nanosized particles by arc discharge. The process was 


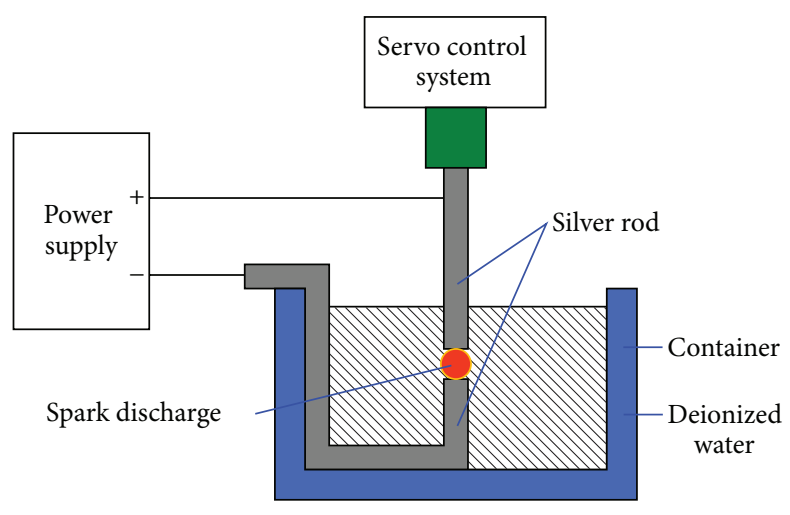

FIGURE 1: ESD nanosilver preparation system framework.

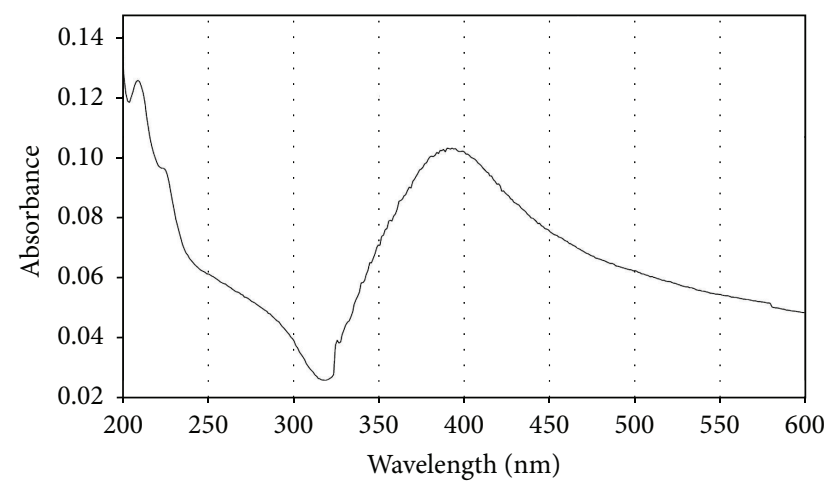

FIGURE 2: UV absorption spectrogram of water phase nanosilver.

free from chemical agents. Only the Pure solutions were prepared such as deionized water or alcohol as the medium. The silver nanoparticles suspending in the dielectric fluid were prepared by setting voltage and current parameters and selecting $\mathrm{T}_{\mathrm{ON}}-\mathrm{T}_{\mathrm{OFF}}$. Easy and mass production is available without pollution, which contributes greatly to the preparation of nanomaterials. However, the characteristics of nanocolloid are closely related to the electrical discharge parameters. During discharge the voltage, current, dielectric fluid, and ambient temperature influenced the concentration of nanosilver colloid and particles size. And silver rod with purity of $99.9 \%$ was selected as the target. The system framework is as shown in Figure 1.

\subsection{Silver Nanofluid Product Analysis}

2.2.1. UV-Vis. UV absorption spectrogram analysis shows the light, among all wavebands from UV to infrared, has resonant effect with water phase nanosilver particles. As different materials have different resonance spectra, the resonance spectrum can be effectively used to prove and analyze for silver material. As shown in Figure 2, the resonance point of water phase nanosilver is at $393 \mathrm{~nm}$.

2.2.2. Nanosizer. The particle distribution of nanofluid was measured by ZS-90 equipment by the Malvern Company. Using this equipment the particle distribution of nanofluid

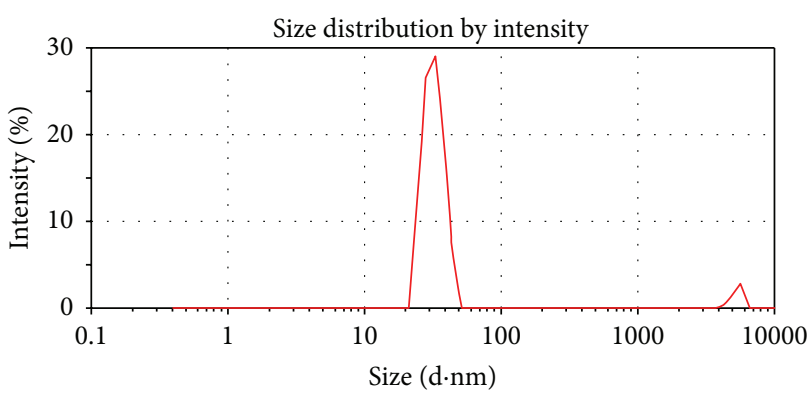

FIgURE 3: Particle size distribution of water phase nanosilver.

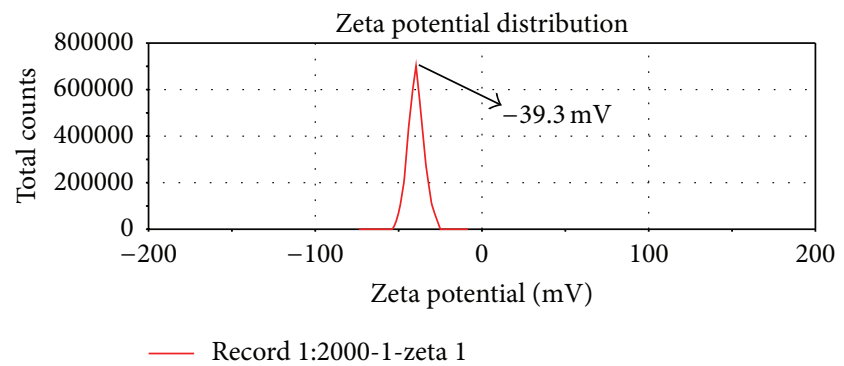

FIGURE 4: Surface potential of water phase nanosilver.

can be known within a few minutes. Figure 3 shows the analysis result of water phase nanosilver prepared by ESD. This equipment is useful in this research due to rapid analysis and low cost.

2.2.3. Surface Potential Analysis. According to the surface potential in Figure 4, the silver nanoparticle surface had $-39.3 \mathrm{mV}$ voltage, and this voltage determined the dispersibility and suspending power of the silver nanofluid. The produced nanoparticles were nanoscale particles; however, under interparticle Van der Waals force and universal gravitation, any particles approaching each other would gather into large particles, which sink when attracted by universal gravitation.

When the surface potential of nanoparticle was greater than $30 \mathrm{mV}$. Exhibit good dispersibility and suspending power. Therefore, silver nanofluid produced by the electric spark method had $-39.3 \mathrm{mV}$ voltage, with excellent suspending and dispersion power, and can be preserved for the long term at normal temperature and pressure.

2.2.4. SEM and EDX. The SEM photo shows the silver nanoparticles in pure water with particle size of about $20 \mathrm{~nm}$, as shown in Figure 5. Then in the EDX component analysis, as shown in Figure 6, the particles were composed of nanosilver.

\section{Experimental Results and Discussion}

Both the nanosilver colloid by the ESD and $\mathrm{AgNO}_{3}$ solution is prepared for making the comparison of antibioactivity potency test. Two tests were conducted: (1) experiment on 
TABLE 1: Experimental result of antibioactive effect of nanosilver.

\begin{tabular}{|c|c|c|c|c|c|}
\hline \multirow[b]{2}{*}{ Dough diameter } & \multicolumn{5}{|c|}{ Dough composition } \\
\hline & $\begin{array}{c}\text { Water }(5 \mathrm{~g}) \\
+ \\
\text { yeast }(4 \mathrm{wt} \%) \\
+ \\
\text { Nanosilver } \\
(0 \text { ppm })\end{array}$ & $\begin{array}{c}\text { Water (5 g) } \\
+ \\
\text { yeast (4 wt } \%) \\
+ \\
\text { Nanosilver } \\
(20 \text { ppm }) \\
\end{array}$ & $\begin{array}{c}\text { Water }(5 \mathrm{~g}) \\
+ \\
\text { yeast }(4 \mathrm{wt} \%) \\
+ \\
\text { Nanosilver } \\
(40 \mathrm{ppm}) \\
\end{array}$ & $\begin{array}{c}\text { Water }(5 \mathrm{~g}) \\
+ \\
\text { yeast }(4 \mathrm{wt} \%) \\
+ \\
\text { Nanosilver } \\
(80 \mathrm{ppm}) \\
\end{array}$ & $\begin{array}{c}\text { Water }(5 \mathrm{~g}) \\
+ \\
\text { yeast }(4 \mathrm{wt} \%) \\
+ \\
\text { Nanosilver } \\
(100 \mathrm{ppm})\end{array}$ \\
\hline Before fermentation $(\mathrm{cm})$ & 3.2 & 3.3 & 3.4 & 3.1 & 3.2 \\
\hline After fermentation (cm) & 4.5 & 4 & 4 & 4.5 & 4.5 \\
\hline
\end{tabular}

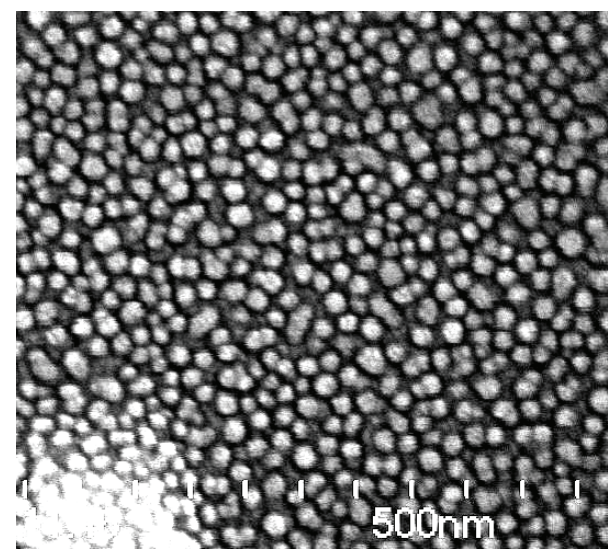

FIGURE 5: SEM photo of nanosilver prepared using pure water.

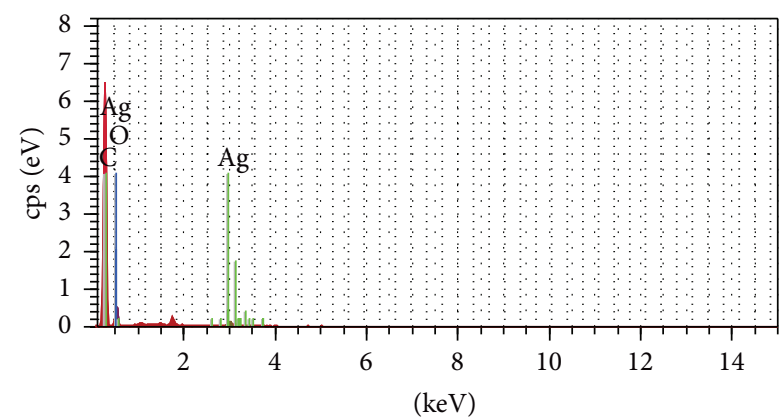

FIGURE 6: EDX component analysis of nanosilver prepared using pure water.

antibioactivity of nanosilver for yeast and (2) experiment on antibioactivity of $\mathrm{AgNO}_{3}$ for yeast.

3.1. Experiment on Antibioactivity of Nanosilver for Yeast. As moisture evaporates during fermentation, a petri dish with a cap was placed on the top of the dough to guarantee weight accuracy. Nanosilver at different concentrations was added in the dough and compared with dough without nanosilver. The result is as shown in Figure 7: (a) before fermentation of dough with only water and yeast, (b) after 3hour fermentation of dough with only water and yeast, (c) before fermentation of dough with $20 \mathrm{ppm}$ nanosilver, (d) after 3-hour fermentation of dough with 20 ppm nanosilver, (e) before fermentation of dough with $40 \mathrm{ppm}$ nanosilver,
TABLE 2: Experimental result of antibioactivity effect of $\mathrm{Ag}^{+}$.

\begin{tabular}{lccc}
\hline & \multicolumn{3}{c}{ Dough composition } \\
& Water $(5 \mathrm{~g})$ & Water $(5 \mathrm{~g})$ & Water $(5 \mathrm{~g})$ \\
Dough diameter & + & + & + \\
& $\begin{array}{c}\text { yeast }(4 \mathrm{wt} \%) \\
+\end{array}$ & $\begin{array}{c}\text { yeast }(4 \mathrm{wt} \%) \\
+\end{array}$ & yeast $(4 \mathrm{wt} \%)$ \\
& $\mathrm{Ag}^{+}(0 \mathrm{ppm})$ & $\mathrm{Ag}^{+}(60 \mathrm{ppm})$ & $\mathrm{Ag}^{+}(120 \mathrm{ppm})$ \\
\hline $\begin{array}{l}\text { Before fermentation } \\
(\mathrm{cm})\end{array}$ & 3.3 & 3.2 & 3.1 \\
$\begin{array}{l}\text { After fermentation } \\
(\mathrm{cm})\end{array}$ & 4.8 & 3.4 & 3 \\
\hline
\end{tabular}

(f) after 3-hour fermentation of dough with 40 ppm nanosilver, (g) before fermentation of dough with 80 ppm nanosilver, (h) after 3-hour fermentation of dough with $80 \mathrm{ppm}$ nanosilver, (i) before fermentation of dough with $100 \mathrm{ppm}$ nanosilver, and (j) after 3-hour fermentation of dough with 100 ppm nanosilver.

It is found that the four groups of dough had similar degrees of fermentation, with the comparison as shown in Figure 8 and Table 1. Moreover, the antibioactive potency was poor, which may be due to insufficient dissociation rate of silver atom released from silver nanoparticle.

3.2. Experiment on Antibioactivity of $\mathrm{AgNO}_{3}$ for Yeast Fermentation. $\mathrm{AgNO}_{3}$ exhibit high ionic mobility in water solution due to high soluble property. The experiment on the antibioactivity of dough with $\mathrm{AgNO}_{3}$ for the yeast is as shown in Figure 9, (a) dough without $\mathrm{AgNO}_{3}$ and with yeast, (b) after 3-hour fermentation of dough without $\mathrm{AgNO}_{3}$ and with yeast, (c) dough with 100 ppm $\mathrm{AgNO}_{3}$ and yeast, (d) after 3hour fermentation of dough with $100 \mathrm{ppm} \mathrm{AgNO}_{3}$ and yeast, (e) dough with $200 \mathrm{ppm} \mathrm{AgNO}_{3}$ and yeast, and (f) after 3hour fermentation of dough with 200 ppm $\mathrm{AgNO}_{3}$ and yeast. The results showed that while dough with $100 \mathrm{ppm} \mathrm{AgNO}_{3}$ was still fermented, its diameter increased by only $0.2 \mathrm{~cm}$, suggesting that the antibioactivity of $\mathrm{Ag}^{+}(60 \mathrm{ppm})$ was significant. Dough with $200 \mathrm{ppm} \mathrm{AgNO}_{3}$ was not fermented; the reason is that the $120 \mathrm{ppm} \mathrm{Ag}^{+}$had killed the yeast completely. Figure 9 and Table 2 show the comparison, suggesting that the silver ion has excellent antibioactivity effect.

The experimental results show that, in the antibioactivity of nanosilver colloid prepared by ESD, the $\mathrm{Ag}^{+}$was more 


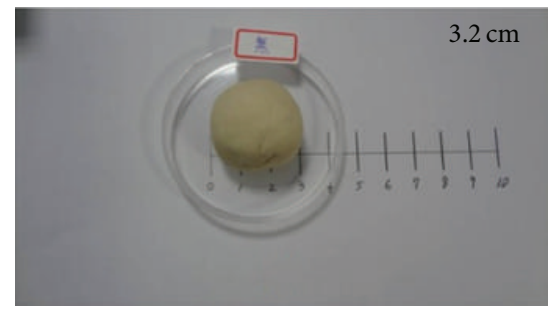

(a)

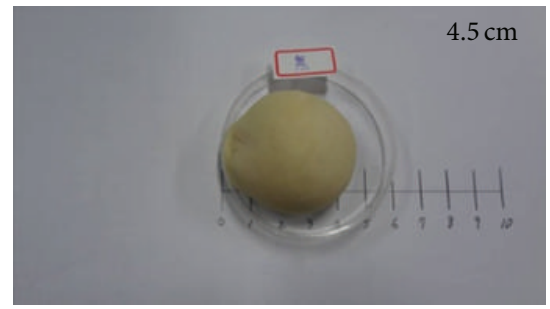

(b)

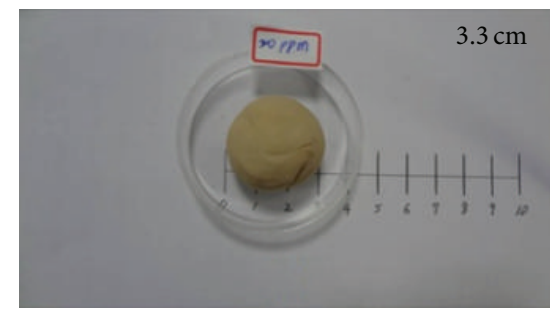

(c)

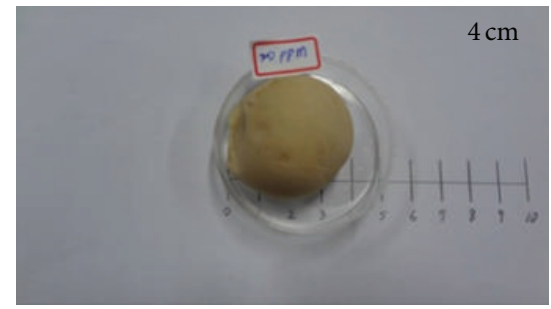

(d)

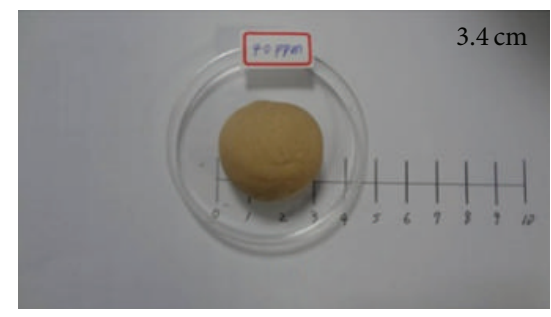

(e)

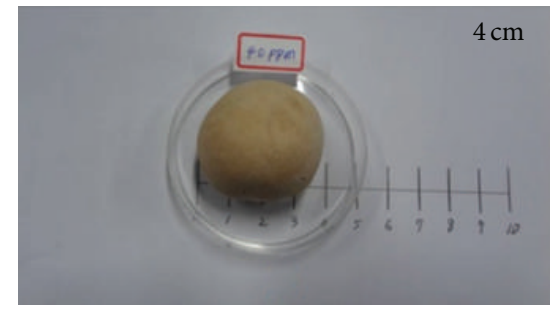

(f)

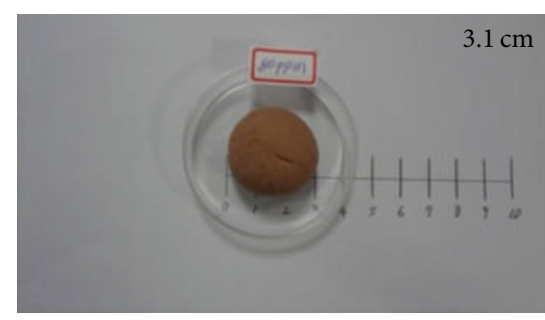

(g)

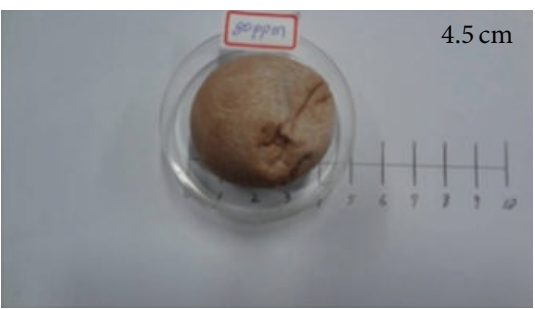

(h)

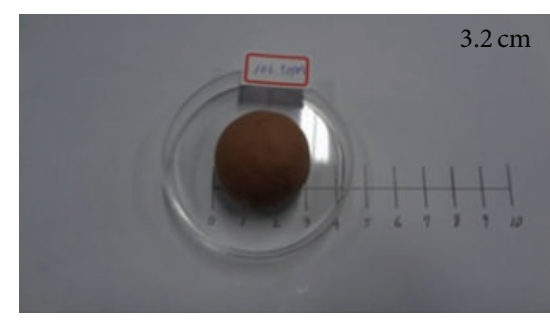

(i)

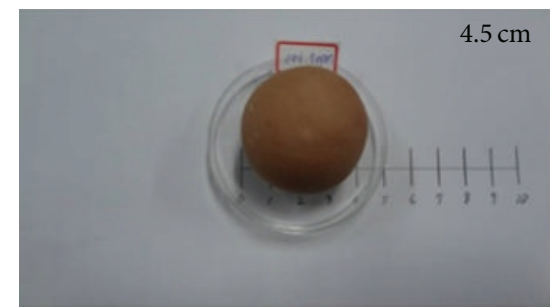

(j)

Figure 7: Experiment on antibioactivity of nanosilver for yeast.

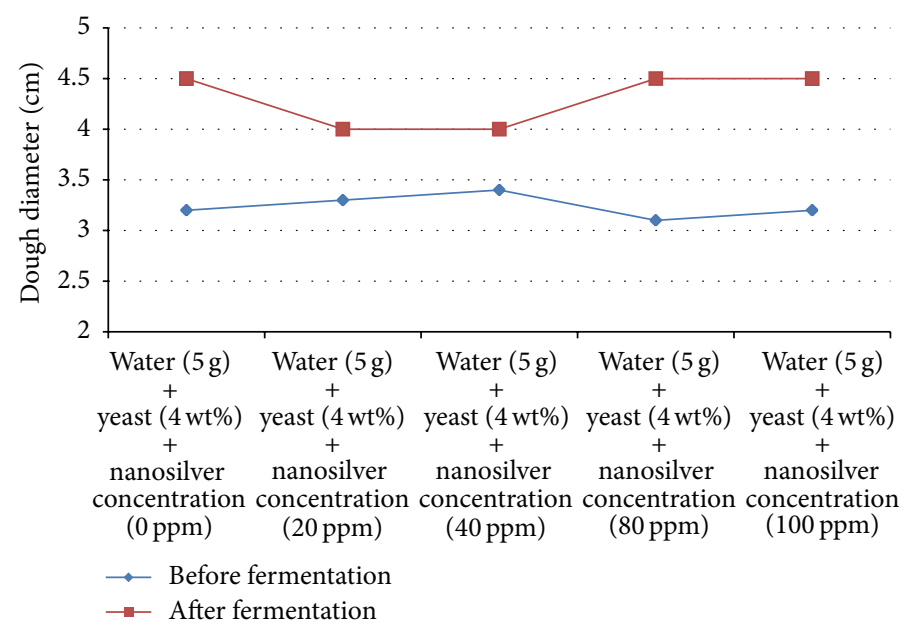

FIGURE 8: Experimental result of antibioactive effect of nanosilver. 


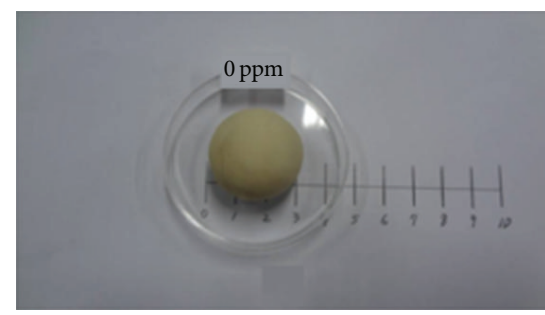

(a)

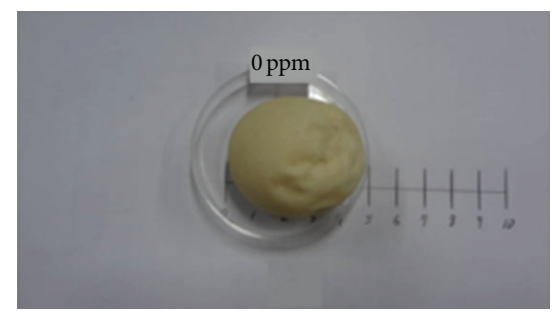

(b)

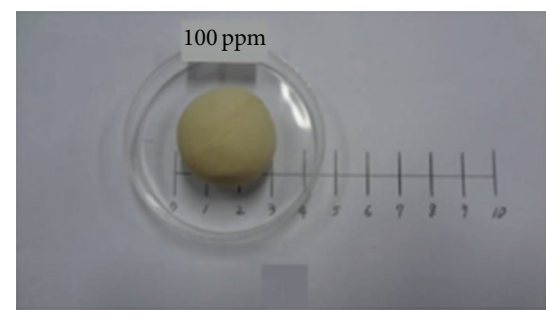

(c)

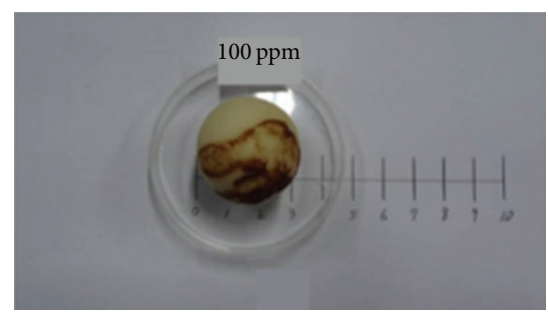

(d)

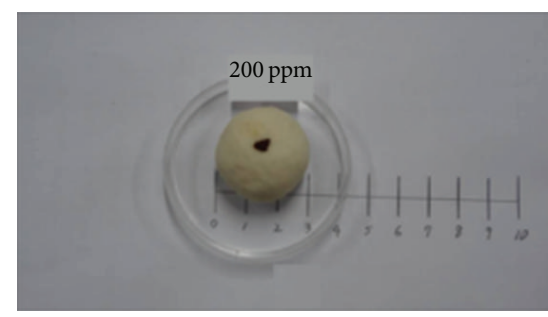

(e)

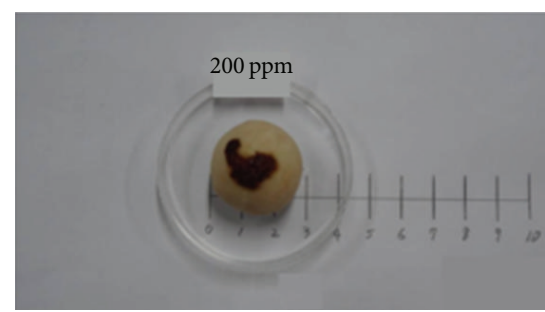

(f)

FIgURE 9: Experiment on antibioactivity of $\mathrm{AgNO}_{3}$ for yeast.

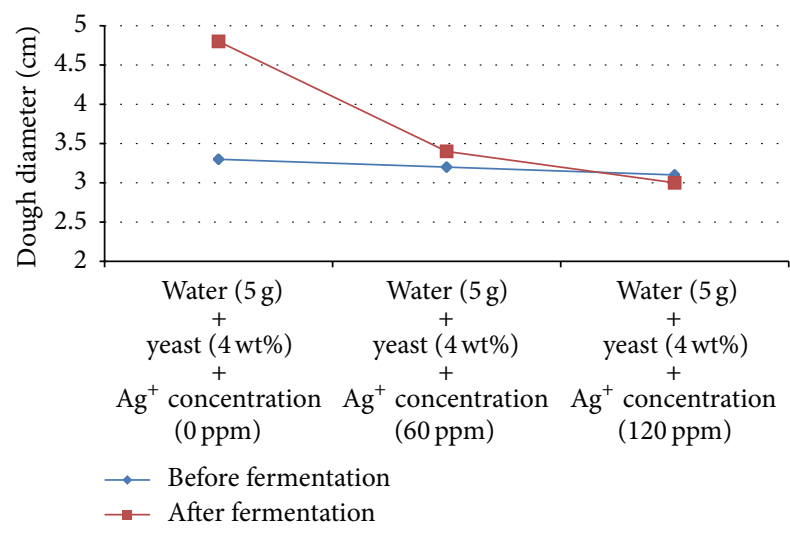

FIGURE 10: Experimental result of antibioactivity of $\mathrm{Ag}^{+}$.

effective than silver nanoparticles at the same concentration (Figure 10). The possibility of dissociation capability of silver nanoparticles can be further explored to promote antibioactivity. In addition, Staphylococcus aureus had 2.8 million 2.903 million base pairs and 2,600 genes, while Escherichia coli had 4.6 million base pairs and 4,000 5,500 genes. The yeast for fermentation had 120 million base pairs and 6,275 genes. Theoretically, the unicellular organisms with more genomes are more powerful to resist the $\mathrm{Ag}^{+}$. Therefore, if nanosilver colloid can eradicate yeast, it can exterminate Staphylococcus aureus and Escherichia coli with less concentration.

\section{Conclusions}

The colloidal silver solution was successfully prepared using ESD without any surfactants, which is different from the traditional chemical process with some toxic chemical agents that may influence the antibioactivity efficacy of colloidal silver experiment. The properties of the self-made nanosilver colloid were analyzed and antibioactivity was tested and concluded, as follows.

(1) According to the particle distribution analysis of water phase nanosilver, the particle size of nanosilver colloid was about $30 \sim 50 \mathrm{~nm}$.

(2) According to surface potential detection, the silver nanoparticle surface had $-39.3 \mathrm{mV}$ voltage, and the surface potential was greater than $30 \mathrm{mV}$; thus, suspension stability was excellent. It is unlikely to deposit at normal temperature and pressure.

(3) The silver nanofluid prepared by ESD had poor antibioactivity due to too low dissociation rate of $\mathrm{Ag}^{0}$, and even if the concentration of nanosilver in the dough increased from $20 \mathrm{ppm}$ to $100 \mathrm{ppm}$ (the highest concentration in this study), it cannot fight against yeast.

(4) The yeast used in this experiment could not resist $100 \mathrm{ppm} \mathrm{AgNO}_{3}$, which is equivalent to $60 \mathrm{ppm}$ silver ion. Previous literature proved that Staphylococcus aureus could not resist $\mathrm{Ag}^{+}$by $20 \mathrm{ppm}$ silver ion; thus, the resistance to silver ion of yeast is about 3 times that of Staphylococcus aureus due to the fact that assumption of genes number of the yeast is three times larger than the genes number of the Staphylococcus aureus.

\section{Conflict of Interests}

The authors declare that there is no conflict of interests regarding the publication of this paper. 


\section{Acknowledgment}

The authors would like to thank the National Science Council of the Republic of China (NSC 102-2221-E-027-035) for financial supporting this research.

\section{References}

[1] B. M. Schumacher, "After 60 years of EDM the discharge process remains still disputed," Journal of Materials Processing Technology, vol. 149, no. 1-3, pp. 376-381, 2004.

[2] K.-H. Tseng, Y.-C. Chen, and J.-J. Shyue, "Continuous synthesis of colloidal silver nanoparticles by electrochemical discharge in aqueous solutions," Journal of Nanoparticle Research, vol. 13, no. 5, pp. 1865-1872, 2011.

[3] S. H. Yeo, W. Kurnia, and P. C. Tan, "Critical assessment and numerical comparison of electro-thermal models in EDM," Journal of Materials Processing Technology, vol. 203, no. 1-3, pp. 241-251, 2008.

[4] K.-H. Tseng, H.-L. Lee, C.-Y. Liao, K.-C. Chen, and H.-S. Lin, "Rapid and efficient synthesis of silver nanofluid using electrical discharge machining," Journal of Nanomaterials, vol. 2013, Article ID 174939, 6 pages, 2013.

[5] K.-H. Tseng and C.-Y. Liao, "Production of silver ions from colloidal silver by nanoparticle iontophoresis system," Journal of Nanoscience and Nanotechnology, vol. 11, no. 3, pp. 1991-1995, 2011.

[6] R. E. Burrell, J. P. Heggers, G. J. Davis, and J. B. Wright, "Efficacy of silver-coated dressings as bacterial barriers in arodent burn sepsis model," Wounds, vol. 11, no. 4, pp. 64-71, 1999.

[7] S. Thomas and P. McCubbin, "A comparison of the antimicrobial effects of four silver-containing dressings on three organisms," Journal of Wound Care, vol. 12, no. 3, pp. 101-107, 2003.

[8] C.-N. Lok, C.-M. Ho, R. Chen et al., "Proteomic analysis of the mode of antibacterial action of silver nanoparticles," Journal of Proteome Research, vol. 5, no. 4, pp. 916-924, 2006.

[9] B. Thati, A. Noble, R. Rowan et al., "Mechanism of action of coumarin and silver(I)-coumarin complexes against the pathogenic yeast Candida albicans," Toxicology in Vitro, vol. 21, no. 5, pp. 801-808, 2007.

[10] C. M. Betbeze, C. C. Wu, S. G. Krohne, and J. Stiles, "In vitro fungistatic and fungicidal activities of silver sulfadiazine and natamycin on pathogenic fungi isolated from horses with keratomysis," American Journal of Veterinary Research, vol. 67, no. 10, pp. 1788-1793, 2006.

[11] F. C. Tenover, "The real vancomycin-resistant Staphylococcus aureus has arrived," Clinical Microbiology Newsletter, vol. 27, no. 5, pp. 35-40, 2005.

[12] S. R. Norrby, C. E. Nord, and R. Finch, "Lack of development of new antimicrobial drugs: a potential serious threat to public health," The Lancet Infectious Diseases, vol. 5, no. 2, pp. 115-119, 2005.

[13] C. Dowsett, "The use of silver-based dressings in wound care," Nursing Standard, vol. 19, no. 7, pp. 56-60, 2004.

[14] D.-C. Tien, K.-H. Tseng, C.-Y. Liao, and T.-T. Tsung, "Identification and quantification of ionic silver from colloidal silver prepared by electric spark discharge system and its antimicrobial potency study," Journal of Alloys and Compounds, vol. 473, no. 1-2, pp. 298-302, 2009.
[15] H. Kaur, S. Kaur, and M. Singh, "Biosynthesis of silver nanoparticles by natural precursor from clove and their antimicrobial activity," Biologia, vol. 68, no. 6, pp. 1048-1053, 2013.

[16] D.-C. Tien, K.-H. Tseng, C.-Y. Liao, and T.-T. Tsung, "Colloidal silver fabrication using the spark discharge system and its antimicrobial effect on Staphylococcus aureus," Medical Engineering and Physics, vol. 30, no. 8, pp. 948-952, 2008.

[17] NewsEdge, "University study shows ionic silver effective against SARS; supports previous research findings on SARS virus," in BioPortfilio by AgION Technologies, 2005.

[18] S. Z. Hamdani, "Study Shows Silver Nanoparticles Attach to HIV-1 Virus," October 2005.

[19] Beiersdorf, Silver Fights Germs Naturally, Curad, 2004.

[20] J. Sripriya, S. Anandhakumar, S. Achiraman, J. J. Antony, D. Siva, and A. M. Raichur, "Laser receptive polyelectrolyte thin films doped with biosynthesized silver nanoparticles for antibacterial coatings and drug delivery applications," International Journal of Pharmaceutics, vol. 457, no. 1, pp. 206-213, 2013.

[21] S. Srinivasan, P. T. S. Kumar, S. V. Nair, K. P. Chennazhi, and R. Jayakumar, "Antibacterial and bioactive $\alpha$ - and $\beta$-chitin hydrogel/ nanobioactive glass ceramic/nano silver composite scaffolds for periodontal regeneration," Journal of Biomedical Nanotechnology, vol. 9, no. 11, pp. 1803-1816, 2013. 

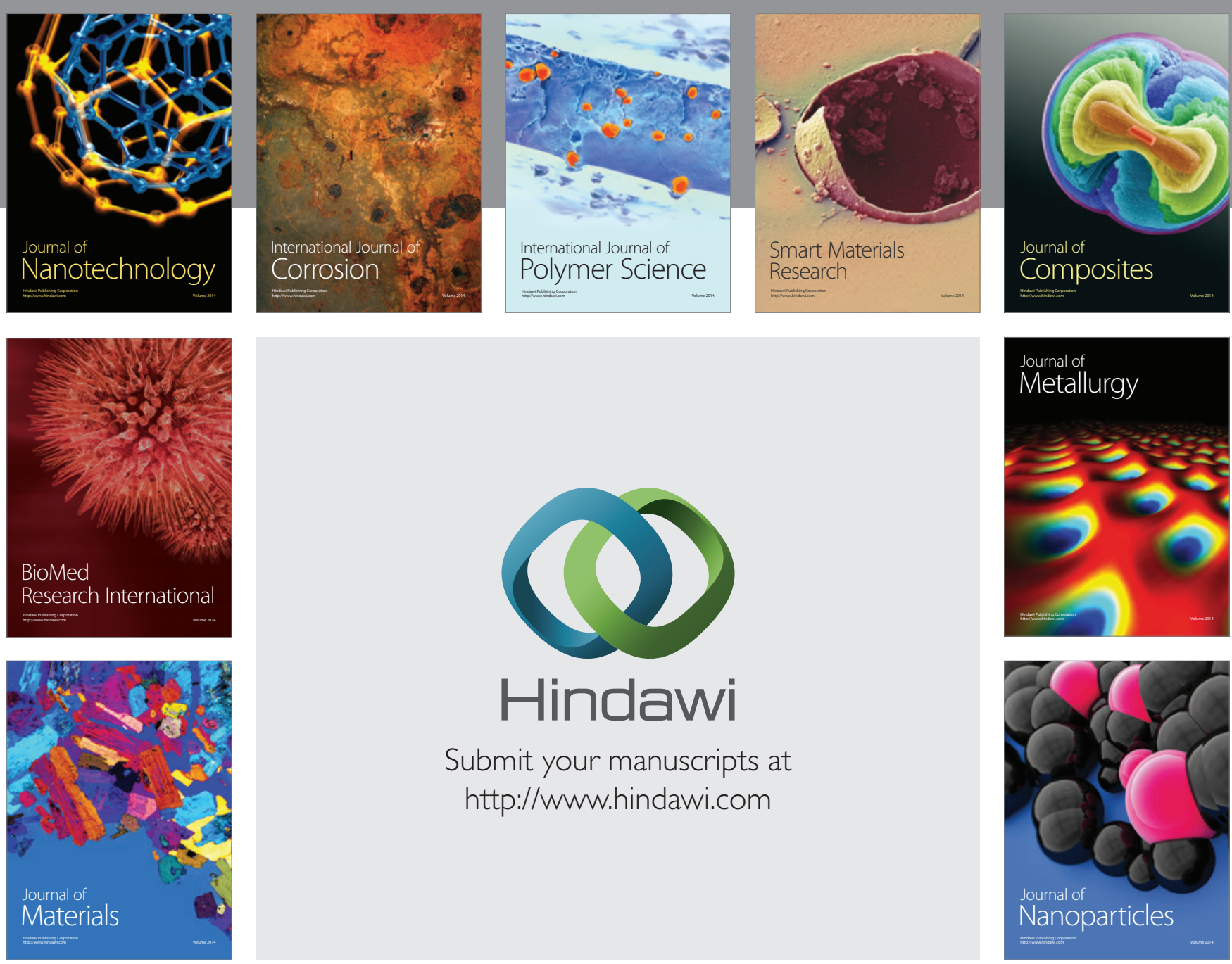

Submit your manuscripts at http://www.hindawi.com
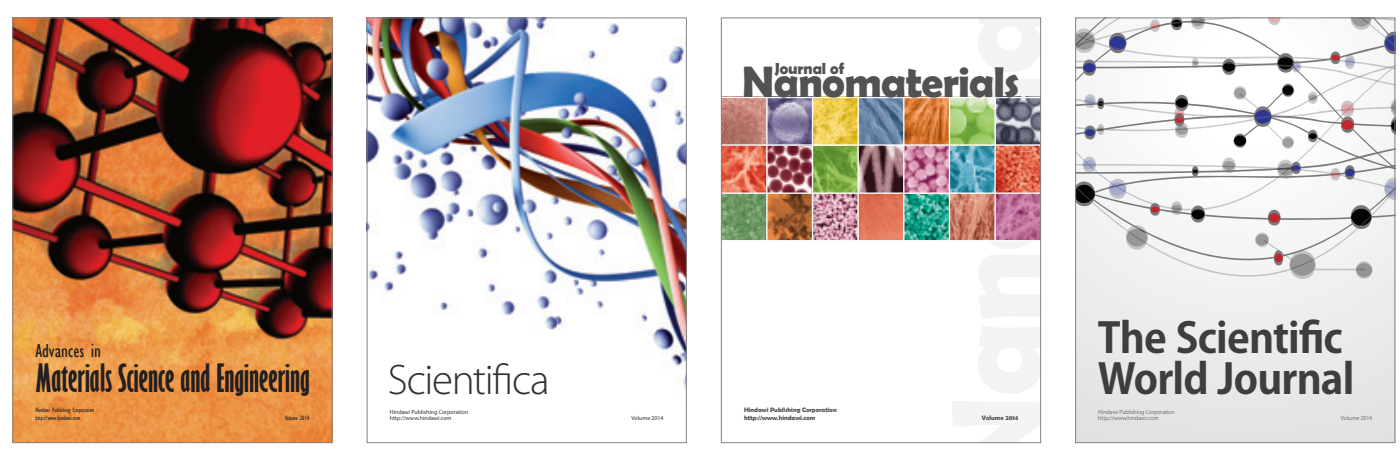

\section{The Scientific World Journal}
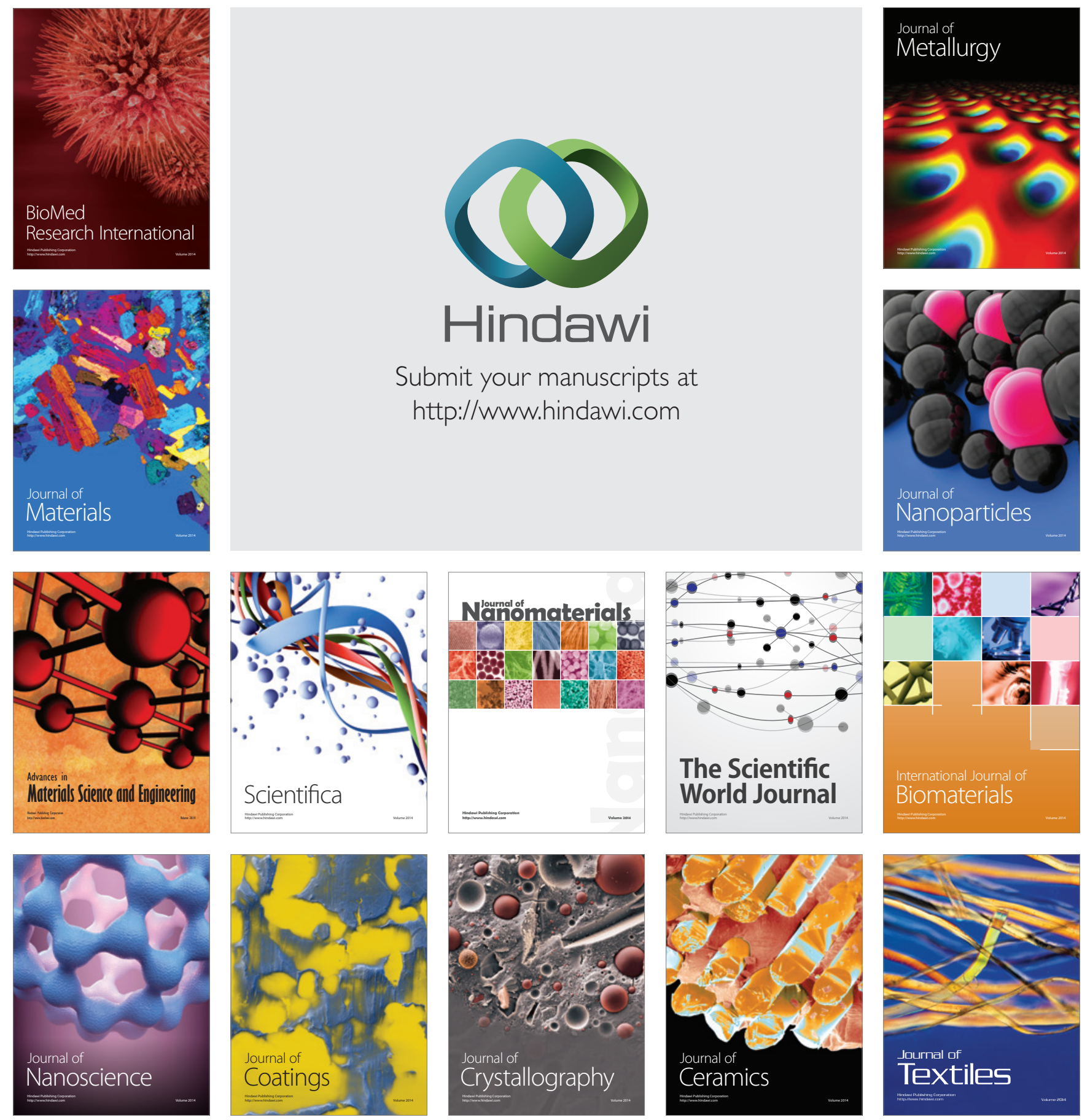